\title{
Architectural Educational Experience in Kansei
}

\author{
Igor Fernández Plazaola ${ }^{1}$, Carmen Llinares Millán ${ }^{1}$, Antoni Montañana Aviñó ${ }^{1}$ and Maria Pons Morera ${ }^{2}$ \\ 1. Lab Human Research Institute, Management Department, Universitat Politècnica de València, Valencia 46022, Spain \\ 2. Management Department, Universitat Politècnica de València, Valencia 46022, Spain
}

\begin{abstract}
Since the earliest Kansei works saw the light more than 30 years ago, the Kansei has boomed exponentially. Because of many and various achieved business successes by different working groups as well as the methodology geographical dispersion throughout the world. Multi-faceted Kansei has been developed for the last 20 years in a very wide and varied way. The Kansei has experienced as if talking of a tree, a branching experience still going on nowadays. Today we can speak from Kansei in theory, Kansei emotion measurement, Kansei engineering, Kansei information, Kansei education, Kansei design to Kansei in practice and many other disciplines. Three years ago, our team started the experience to introduce Kansei in the educational atmosphere, applying it to the final degree projects. In the School of Building Engineering at the Universitat Politècnica de València and inside its final degree project proposal, a workshop on Kansei engineering was offered. During these years at the eighth semester of the building engineer degree, students have been working for almost five months under the supervision of a team of teachers on their final project till the final public oral defense was made in front of a committee. During these years, we have worked with an average of 10 students per year. Some have successfully completed their final projects, others have not achieved the minimum required. The article aims to explain the experience during the last three years the team has accumulated in Kansei education, and can be of interest for every teacher or lecturer.
\end{abstract}

Key words: Academic Kansei, Kansei final project, educational experience, architectural teaching.

\section{Introduction}

Kansei has been spreading around the world for over these last 30 years. As a result of many and various achieved business successes by different working groups, and because of its inner interest and the worldwide spread of its methodology. Nowadays we can find a huge range of different ways of using Kansei and its extension itself.

The orderliness covered are numerous and diverse increasing since 1878, when Amane Nishi characterized the Kansei term in an academic context for the first time. Following Refs. [1, 2], we can find differences between Kansei engineering, Kansei science [3] and Kansei design or Kansei sociology [4], we can find, as well, the term Kansei associated with marketing $[5,6]$.

As a reflection of this we only have to take a look

Corresponding author: Igor Fernández Plazaola, assistant lecturer, research field: subjective measurement of architectural perception. into KEER (International Kansei Engineering \& Emotion Research Conference) itself where we can find a various set of disciplines. One of the KEER scopes is to attempt to represent most facets of the areas in which Kansei research is carried out. The conference will therefore include different Kansei aspects such as Kansei theory, Kansei emotion measurement, Kansei information, Kansei education, Kansei engineering till Kansei in practice.

In our day by day routine, we have been including and living with Kansei in various facets. Kansei has become an important part of our lives, started reading and assimilating after we tried to discover and experience ending with new investigations and publications. We started with the earlier Kansei stages and nowadays we are working with Kansei and the new ICT (information communication and technologies). All this involves expending great time with different Kansei areas. Most of us are university teachers and one of our higher ambitions is to unify teaching and research in order to keep both at the top 
possible level.

This objective, easy to understand, helps us to focus on one knowledge and scientific area so that all our efforts have a unique target helping us to be more efficient at teaching and scientific level. Within this context our working group tried to join both our teaching and our scientific objectives, and we found the clue due to the Bologna process of adaptation to the new draft EHEA (European Higher Education Area).

This paper's objective is to describe a Kansei educational experience. We aim to describe the processes followed to involve and motivate building engineer students non-indoctrinated with Kansei methodologies. Showing the results obtained not only in a quantitative way but also from the different surveys and interviews with the pupils.

The paper may be of interest to every single teacher with Kansei feelings, and research groups in order to know the viability of such methodologies.

\section{Educational Environment}

The process of adaptation to the EHEA has brought significant changes in the methodology of university education through the new ECTS (European Credit Transfer System). However, the implementation by universities is not limited to adapt program content to a new structure, but also implies a deeper transformation requiring a methodological renewal that includes changes in teaching methods and procedures to be used in the development of the teaching-learning process. With this opportunity of paradigm change, the need to implement Kansei education was reachable.

This scenario also includes the FP (final project) development as main part of our experience. The FP is developed in a different way to all the other subjects of the university curriculum as Caro et al. [7] said, and is mandatory at the end of university studies as it should reflect all the knowledge and skills acquired during the degree.
At Spanish universities and according to the "Libro blanco" [8], final degree project is developed during the eighth semester, and has a teaching order of 12 ECTS where they should develop the competencies, skills and following abilities:

- integrate training content received in a construction project and its management;

- research in one of the lines established by the departments;

- exchange with other schools in the framework of national and international relations;

- conducting educational cooperation agreements signed by the university and the administration or public and private undertaking.

The ETSIE (School of Building Engineering) of the UPV (Universitat Politècnica de València), in order to adapt to the new EHEA, implemented a new system that through scientific-technical workshops which were initiated in 2010 2011 academic year, on the purpose to prepare the final project degree in building engineer by UPV. These workshops had to be carried out during $4 \frac{1}{2}$ months and attended between 4 and 15 students per group, supervised by a team of teachers till they reached their final public defense. The pedagogical methodology used in the final project workshops is based on PBL (project-based learning) activities. This active teaching methodology has a holistic approach to education and is designed to engage students in authentic research problems [9], so it obviously differs from traditional teaching processes [10].

This paper aims to show how Kansei methodology has been used in an educational environment and has been applied to such an interesting, immersive and important subject such as the final project.

\section{Teaching Methodologies}

\subsection{Workshop Description}

Within this entire environment, our group formed by the four authors found the key to develop a Kansei educational experience. The main aim was to 
experience the possibility of developing a Kansei study with non-indoctrinated people in a bit more than four months, and this work had the entity that a university's final project demands.

The workshop has been offered for the last three years since 2011. The workshop has been tendered to the students as "new techniques for designing user-oriented architectural spaces.” The ETSIE workshop's complete offer was about 40 different areas and all of them related to architecture, building technologies, building management, building rehabilitation, and energy efficiency among others. The amount of pupils who demand final project workshops have been about 400 students per year, having each workshop between 4 to 15 students. All students were completely free to choose the workshop they wanted to attend until it was full. Once one workshop was full, it was closed for new applicants.

The overall objective of the workshop had as said before two main objectives: on one side to practice educational Kansei experience; on the other hand to develop a FP (final project) at university level. All these used KE (Kansei engineering) methodology to study architectural spaces. As is well known from Nagamachi [11], the methodology consists in finding the relationship between the perception that a product has according to its own user language, the various designing parameters that define such product and product assessment as a whole.

Students have to realize that, in order to design a product, it is essential to involve every single participant on the project within the designing process, the end user, sales men, production technicians, designers, quality controllers and so on. This way of project management is used in many industrialized sectors. However, when it is related to architecture and the building sector, this is not so common, the end user and even all the intermediate stakeholders, suppliers or partners involved in the construction process are not usually part of the designing and architectural process. With this aim, students must analyse the perceptions and identify the designing elements and parameters that cause those perceptions through different architectural spaces of the Universitat Politècnica de València. In particular, students should be able to:

- assimilate the concepts of "Kansei methodology" research and apply it to the design of an architectural space;

- develop "KE" research methodology (affinity diagram, fieldwork and statistical data processing);

- analyse research data;

- discuss the results and research methodology;

- attend and guide an oral public defense of his work.

Pupils have to deliver three main things by the end of the semester: one essay describing their whole work; an oral defense in front of a committee; and a poster as a synthesis of the whole work and in order to disseminate workshop results.

In order to show the workshop structure, the FP essay structure is as seen in Table 1.

\subsection{Workshop Structure and Methodology}

The methodology used in the FP workshops is based on the PBL technique, which is an active learning-teaching procedure. This methodology was chosen to allow students to use an independent way of learning, with mentoring and supervision by the workshop supervisors in order to acquire research skills. With the purpose of keeping a correct supervision and establishing some milestones, a number of present and group sessions were established. The total compulsory minimum classroom hours were 20, and they were divided into 10 sessions of two hours per session (spare).

The classroom activities were organized according to the objectives to be achieved in each of the different session. These activities were reflected in:

- theoretical sessions (30\%) to provide students with a guide or basic guidelines for learning the methodology and other needs they may have; 
Table 1 Final project essay structure.

\begin{tabular}{|c|c|c|}
\hline \multicolumn{3}{|c|}{ Workshop structure } \\
\hline Position & Name & Concept \\
\hline 1 & Introduction & Defining the essay aim, and project description \\
\hline 1.1 & Background & \\
\hline 1.2 & Essay Structure & \\
\hline 2 & Literature Review & Analyzing what has been studied about their project \\
\hline 2.1 & Design Techniques of User-Oriented Products & \\
\hline 2.2 & Studies of Perception and Semantic Differential & \\
\hline 2.3 & Studies of Architectural Space & \\
\hline 3 & Objectives and Hypothesis & Setting the research starting points \\
\hline 3.1 & Objectives & \\
\hline 3.2 & Hypothesis & \\
\hline 4 & Materials and Methods & $\begin{array}{l}\text { Identify key design elements of architectural spaces } \\
\text { causing a positive overall rating in the user }\end{array}$ \\
\hline 4.1 & Identifying Perceptions Resulting from the Architectural Space & \\
\hline 4.2 & Getting the Design Elements Associated with the Architectural Space & \\
\hline 4.3 & Development of Questionnaires & \\
\hline 4.4 & Selection and Sample Size & \\
\hline 4.5 & Development of the Fieldwork & \\
\hline 4.6 & Data Processing and Statistical Analyses by Using SPSS & \\
\hline 5 & Results & Results analysis \\
\hline 6 & Conclusions & Drawn conclusions \\
\hline 7 & References & \\
\hline
\end{tabular}

- development, analysis and discussion of data and methodology $(57.5 \%)$ contrasting impressions with students and analysing all their collected data;

- individual work (12.5\%) guided by the teacher at class.

At the end of each different session, the student got a stunt of activities they must develop for the next one. These tasks were a part of the final essay to be developed as well as the implementation and drafting of research. Another important aspect is that the FP development is completely individual. However, there are tasks that require cooperative character such as data collection and fieldwork for the survey collection, where students worked together and developed teamwork skills.

Table 2 shows the activities that are taking place, both in the classroom and independent work of the student according to the objectives for each session.

\subsection{Workshop Assessment}

The whole evaluation is a continuous and formative task, thought pupils have been personnel guided right since the beginning. The pupil advance and the essay is assessed in every milestone having had more than four reviews before the final one. Every evaluation is formative and is discussed with each of the students personally face to face. Before their final oral defense, they need to be assessed by the FP supervisors who are the workshop teachers. This final supervision determines who can attend the final oral defense and who has not reached the minimum level required for a FP. Every student gets a final inform from its supervisor that allows them to go into the last step which is the final oral defense. This final inform by the FP workshop responsible will be issued if the student has developed the FP working properly and therefore developed all outdoor activities and attended all FP sessions.

The final FP assessment is conducted by a committee appointed for this purpose. The committee is made up by three teachers, two selected by lot and the third one invited by the workshop supervisors. The 
Table 2 Workshop structure.

\begin{tabular}{|c|c|c|c|c|}
\hline Week & Objective & Classroom activity (2 h/week) & Outdoor activity & Assessment \\
\hline 1 & \begin{tabular}{|l|} 
Students must assimilate \\
the concepts of KE \\
methodology in order to \\
apply it to the design of an \\
architectural space.
\end{tabular} & $\begin{array}{l}\text { Workshop introduction: objectives, } \\
\text { methodology, evaluation, structure }(1 \mathrm{~h}) \text {; } \\
\text { Explanation and introduction to the } \\
\text { methodology of KE. Information is } \\
\text { provided }(0.5 \mathrm{~h}) ; \\
\text { Explanation of how perceptions and } \\
\text { design elements of an architectural space } \\
\text { are collected }(0.5 \mathrm{~h}) \text {. }\end{array}$ & $\begin{array}{l}\text { Pickup perceptions or } \\
\text { expressions that generate the } \\
\text { architectural spaces and } \\
\text { design elements by visiting } \\
\text { buildings and spaces of the } \\
\text { university, journal and book } \\
\text { review, etc.; } \\
\text { Bring pictures of different } \\
\text { spaces; } \\
\text { Provide reading literature. }\end{array}$ & Workshop attendance. \\
\hline 2 & $\begin{array}{l}\text { Students must be able to } \\
\text { perform the affinity } \\
\text { diagram perceptions or } \\
\text { expressions that generate } \\
\text { the offices and develop } \\
\text { the literature review } \\
\text { chapter. }\end{array}$ & $\begin{array}{l}\text { diagrams or expressions that } \\
\text { perceptions cabinets }(2 \mathrm{~h}) \text {. }\end{array}$ & $\begin{array}{l}\text { Bibliographic research } \\
\text { information of the concept of } \\
\text { KE as well as research } \\
\text { methodology; } \\
\text { Writing chapter of the } \\
\text { literature review. }\end{array}$ & $\begin{array}{l}\text { Workshop attendance; } \\
\text { Evaluation of the } \\
\text { information provided } \\
\text { by the student in the } \\
\text { collected perceptions } \\
\text { and participation in the } \\
\text { activity. }\end{array}$ \\
\hline 3 & \begin{tabular}{|l|} 
Students must be able to \\
perform the affinity \\
diagram design elements \\
that make up the \\
architectural spaces and to \\
develop the methodology \\
chapter done so far.
\end{tabular} & $\begin{array}{l}\text { Affinity diagrams of the design elements } \\
\text { that make up the offices }(2 \mathrm{~h}) \text {. }\end{array}$ & $\begin{array}{l}\text { Writing the literature review } \\
\text { chapter; } \\
\text { Writing the methodology } \\
\text { development up to now. }\end{array}$ & $\begin{array}{l}\text { Workshop attendance; } \\
\text { Evaluation of the } \\
\text { information provided } \\
\text { by the student design } \\
\text { elements contained and } \\
\text { participation in the } \\
\text { activity. }\end{array}$ \\
\hline 4 & $\begin{array}{l}\text { Students must be able to } \\
\text { carry out the field study } \\
\text { and develop the } \\
\text { methodology chapter done } \\
\text { so far. }\end{array}$ & $\begin{array}{l}\text { Preparation of the survey }(1 \mathrm{~h}) \text {; } \\
\text { Presentation of the process through } \\
\text { surveys and data collection }(1 \mathrm{~h}) ; \\
\text { Collection of essays: a literature review. }\end{array}$ & $\begin{array}{l}\text { Fieldwork; } \\
\text { Write the methodology } \\
\text { developed to this point. }\end{array}$ & $\begin{array}{l}\text { Workshop attendance; } \\
\text { Evaluation of the } \\
\text { literature review. }\end{array}$ \\
\hline 6 & $\begin{array}{l}\text { Students must be able to } \\
\text { analyse objective data. }\end{array}$ & $\begin{array}{l}\text { Session data statistical processing and } \\
\text { objective parameters }(1 \mathrm{~h}) \text {; } \\
\text { Comment results }(1 \mathrm{~h}) \text {. }\end{array}$ & $\begin{array}{l}\text { Analyse results and draw up } \\
\text { to this point (methodology } \\
\text { and results). }\end{array}$ & $\begin{array}{l}\text { Workshop attendance; } \\
\text { Evaluation of the } \\
\text { methodology and } \\
\text { results to this point. } \\
\end{array}$ \\
\hline 7 & $\begin{array}{l}\text { Students must be able to } \\
\text { analyse the subjective data } \\
\text { (perceptions). }\end{array}$ & $\begin{array}{l}\text { Statistical data processing perceptions } \\
(1 \mathrm{~h}) \text {; } \\
\text { Comment results }(1 \mathrm{~h}) \text {. }\end{array}$ & $\begin{array}{l}\text { Interpret results and draw up } \\
\text { to this point (methodology } \\
\text { and results). }\end{array}$ & $\begin{array}{l}\text { Workshop attendance; } \\
\text { Evaluation of the } \\
\text { methodology and } \\
\text { results to this point. } \\
\end{array}$ \\
\hline 8 & \begin{tabular}{|l|} 
Students must be able to \\
analyse the subjective data \\
(perceptions and design \\
elements).
\end{tabular} & $\begin{array}{l}\text { Statistical data treatment and design } \\
\text { elements relating to perceptions }(1 \mathrm{~h}) \text {; } \\
\text { Comment results }(1 \mathrm{~h}) \text {. }\end{array}$ & $\begin{array}{l}\text { Interpret results and draw up } \\
\text { to this point (methodology } \\
\text { and results). }\end{array}$ & $\begin{array}{l}\text { Workshop attendance; } \\
\text { Evaluation of the } \\
\text { methodology and } \\
\text { results to this point. }\end{array}$ \\
\hline 9 & $\begin{array}{l}\text { Students should be able to } \\
\text { write conclusions. }\end{array}$ & $\begin{array}{l}\text { Individual working session }(1 \mathrm{~h}) \text {; } \\
\text { Review papers: methodology and results } \\
(1 \mathrm{~h}) \text {. }\end{array}$ & $\begin{array}{l}\text { Correction of mistakes; } \\
\text { Write conclusions. }\end{array}$ & $\begin{array}{l}\text { Workshop attendance; } \\
\text { Evaluation of the FP. }\end{array}$ \\
\hline 10 & \begin{tabular}{|l|} 
Students should be able to \\
develop oral \\
communication and \\
presentation and FP panel.
\end{tabular} & $\begin{array}{l}\text { FP final presentation session }(1 \mathrm{~h}) \text {; } \\
\text { Review of complete essays }(1 \mathrm{~h}) \text {. }\end{array}$ & $\begin{array}{l}\text { Mistakes corrections and } \\
\text { final doubts. }\end{array}$ & $\begin{array}{l}\text { Workshop attendance; } \\
\text { Exposure assessment } \\
\text { and poster. }\end{array}$ \\
\hline
\end{tabular}

minimum requirements for the oral defense are:

- The student must have passed the total credits of the degree except the FP;

- Students must have been authorized by their academic director or person in charge of the FP workshop.

The final qualification obtained in the FP has been changing during these three years. In the two first years 2011 2012, the 70\% of the final qualification was assessed by the pupil supervisor and $30 \%$ by the 
committee. This has changed in 2013 when the whole assessment correspond to the committee.

\subsection{Workshop Dissemination}

In order to make the workshop result visual and to spread the knowledge, every single student attending the oral defense is asked to prepare a poster of his individual work (Fig. 1). These posters are exposed in two different exhibitions centres. The first one is the ETSIE exhibition room and the secondone is "Salon

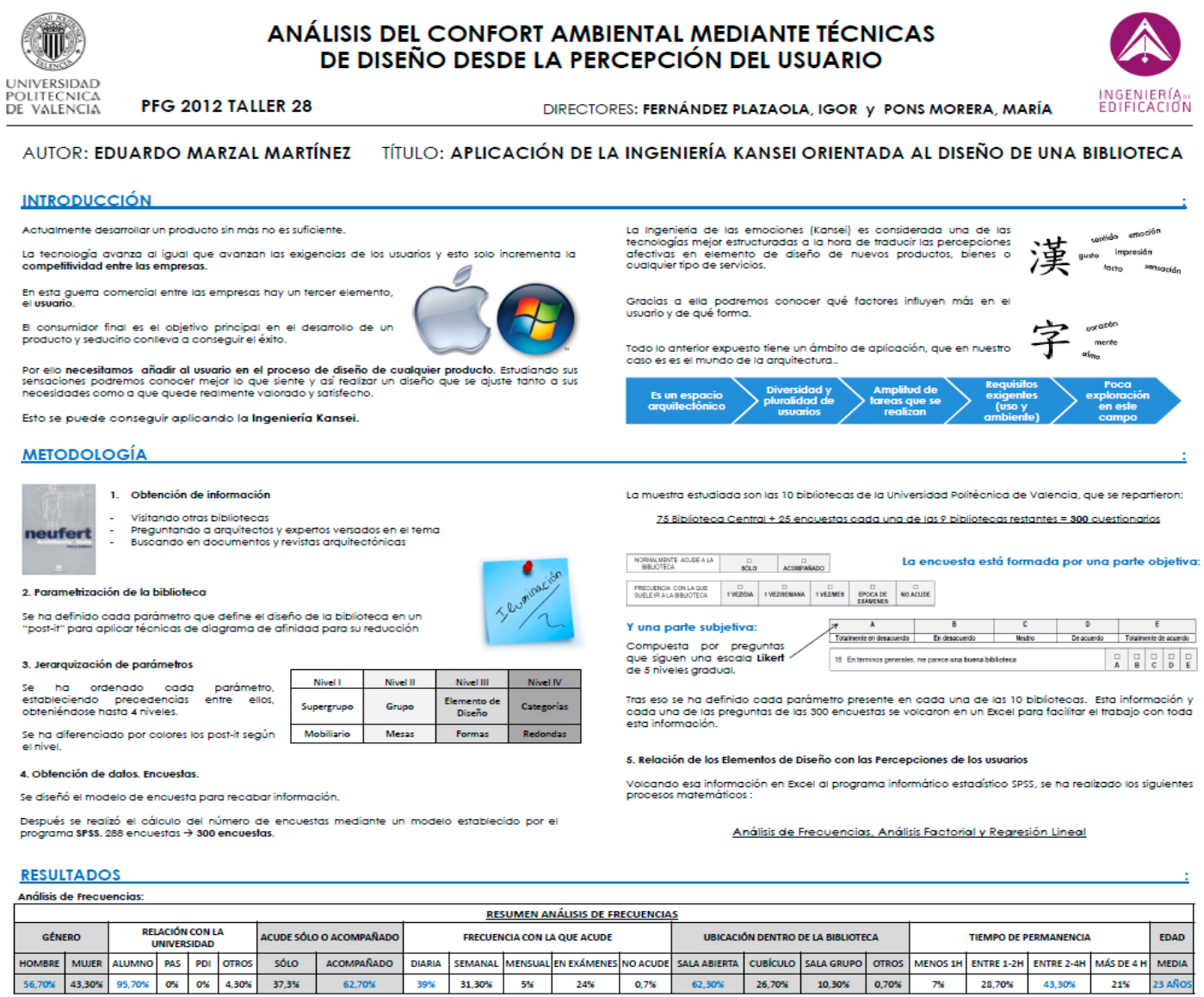

Análisis Factorial de los Ejes semánticos:

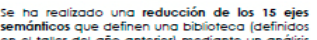
en el trole
foctorial.

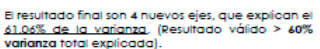
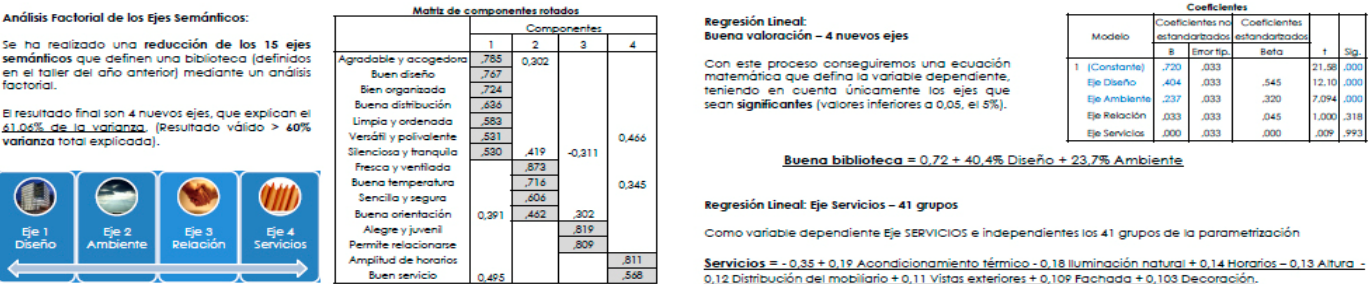

Buena biblioteca $=0,72+40,450$ Diseño $+23,75$ Ambiente

Regresión Lineat Eje Servicios - 41 grupos

Como variabie dependiente Eje SERVicIOS e independientes los 41 grupos de la parametrización

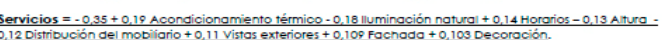

CONCLUSIONES

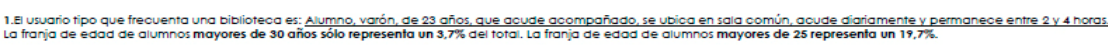

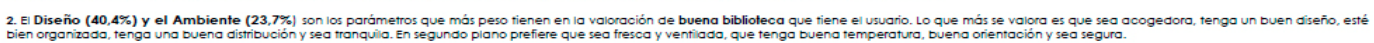

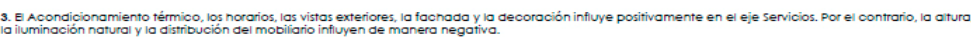

4. Se redujeron los 41 grupos en 11 nuevos que expicaban el 63,73\% de la varianza. Se nan denominado, por orden:

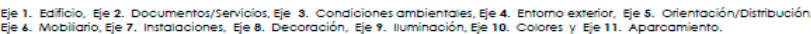

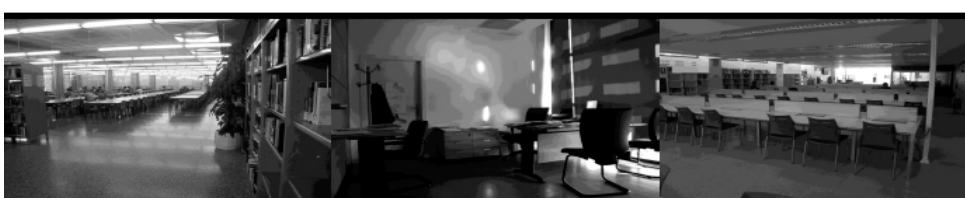

Fig. 1 Sample student panel. 
Tecnológico Internacional de la Construcción" EXCO (International Building Technology Exhibition).

This task prepares them to synthesize the whole work developed during the last four months and to prepare their oral defense.

\section{Results and Conclusions}

There are two types of results: the quantitative ones obtained from the enrolled students, its assistance, final qualifications and so on; and the qualitative ones obtained from different surveys and interviews with the pupils that end to be almost colleagues at the very end of the workshop.

According to the results shown in Table 3, the percentage of projects oral defended has been increasing throughout the years. Although not shown, the percentage of the first year non-defended (because they do not met the minimum) students was $55.56 \%$. Despite this, we can highlight that $60 \%$ of those non-defended, repeated the same workshop in the following year (Table 4). This is due to two reasons: The student has not passed the entire total credits of the degree except the FP, and student's interest in the FP development.

Moreover, to assess the results of the implementation of scientific and technical workshop, in-depth interviews were conducted with randomly selected students to extract certain relevant data. As a result, the students improve their affinity to an area of research prior unknown. However, they expressed a high difficulty in developing the research, due to the results of the users' subjective impressions assessing architectural spaces. These were sometimes different and contradictory with their technical point of view. Another aspect to the fore of qualitative research is student's satisfaction about the FP when finalized, when in principle, it seemed to take on a difficult challenge.

In the qualitative side, the pupils chose our workshop among others even though ours was the furthest in content regarding to their studies. This was a surprise because at the beginning, with the previous workshop information they had, almost none of them really knew what it was about. The beginnings were very difficult because they could hardly understand the methodology and the final objective. Speaking about relations between perceptions and design parameters sounds magic to them. This image was completely changed in the $100 \%$ of the cases once they were able to analyse the statistical data.

For our team, the Kansei educational experience has been successful during these three academic years. But also has to be said that the workshop instructors consider that a huge effort is required by both the student and the teacher to develop the PBL methodologies within the Kansei area at ETSIE. In fact, according to the results shown in Table 3, it can be seen that the enrolment exceeds the limit of 15

Table 3 Enrolled, submitted and not submitted students to the workshop during the three academic years.

\begin{tabular}{|c|c|c|c|c|c|c|}
\hline \multirow{2}{*}{ Types } & \multicolumn{2}{|c|}{ Course 2010 2011 } & \multicolumn{2}{|c|}{ Course 2011 2012 } & \multicolumn{2}{|c|}{ Course 2012 2013 } \\
\hline & Number & Percentage (\%) & Number & Percentage (\%) & Number & Percentage (\%) \\
\hline Enrolled & 18 & - & 16 & - & 13 & - \\
\hline Approved & 8 & $44.44 \%$ & 10 & $62.50 \%$ & 10 & $76.92 \%$ \\
\hline Suspended & 10 & $55.56 \%$ & 6 & $37.50 \%$ & 3 & $23.07 \%$ \\
\hline
\end{tabular}

Table 4 Repetition ratios of the failed students.

\begin{tabular}{|c|c|c|c|c|c|c|}
\hline \multirow{2}{*}{ Types } & \multicolumn{2}{|c|}{ Course 2010 2011 } & \multicolumn{2}{|c|}{ Course 2011 2012 } & \multicolumn{2}{|c|}{ Course 2012 2013 } \\
\hline & Number & Percentage $(\%)$ & Number & Percentage $(\%)$ & Number & Percentage $(\%)$ \\
\hline Suspended & 10 & - & 6 & - & 4 & - \\
\hline Registered for the following year & 6 & $60.00 \%$ & 3 & $50.00 \%$ & 2 & $50 \%$ \\
\hline Not enrolled for the following course & 4 & $40.00 \%$ & 3 & $50.00 \%$ & 2 & $50 \%$ \\
\hline
\end{tabular}


planned on the scientific-technical ETSIE workshops because of an accepted demand. So, after the experience of the first workshop course, the decision was not to increase the number of students for next editions, despite that it was proposed for next courses, to develop FP work in pairs to reduce the total effort.

\section{References}

[1] Shimizu, Y., Sadoyama, T., Kamijo, M., Hosoya, S., Hashimoto, M., Otani, T., et al. 2004. "On-demand Production System of Apparel on the Basis of Engineering." International Journal of Clothing Science and Technology 16 (1/2): 32-42.

[2] Lévy, P. 2013. "Beyond Kansei Engineering: The Emancipation of Kansei Design.” International Journal of Design 7 (2): 83-94.

[3] Harada, A. 2003. "Promotion of Kansei Science Research." In Proceedings of the 6th Asian Design Conference, 49-51.

[4] Takeda, T. 2006. "Sociological Approach to Kansei." Journal of Japan Society of Kansei Engineering 6 (2): 67-72.

[5] Dentsu Inc. 1985. Kansei Consumption, Logic
Consumption. Tokyo: Nihon Keizai Shinbunsha.

[6] Fujioka, W. 1984. Goodbye, Mass-How to Read Kansei Age? Kyoto: PHP (Peace and Happiness through Prosperity) Research Center.

[7] Caro, M. A., Rodríguez, A., Calero, C., Fernandez-Medina, E., and Piattini, M. 2005. "Analysis and Review of the Literature in the Context of Final Year Projects: A Proposal." Chilean Society of Computer Science Magazine 6 (1): 1-9.

[8] National Agency for Quality Assessment and Accreditation. 2004. White Paper Degree in Building Engineering. Madrid: National Agency for Quality Assessment and Accreditation.

[9] Blumenfeld, P. C., Soloway, E. M., Ronald W. K., Joseph S. G. M., and Palincsar, A. 1991. "Motivating Project-Based Learning: Sustaining the Doing, Supporting the Learning." Educational Psychologist 26 (3): 369-98.

[10] Kubiatko, M., and Vaculová, I. 2011. "Project-Based Learning: Characteristic and the Experiences with Application in the Science Subjects." Energy Education Science and Technology Part B: Social and Educational Studies 3 (1): 65-74.

[11] Nagamachi, M. 1989. Kansei Engineering. Tokyo: Kaibundo Publishing Co. Ltd. 